\title{
PREVALENCE OF RISK FACTORS AMONG WOMEN WITH OSTEOPOROSIS
}

Dalibor Stajic ${ }^{1}$, Sandra Zivanovic ${ }^{2}$, Ana Miric ${ }^{1}$, Marija Sekulic $^{1}$, Nela Djonovic ${ }^{1,3}$ ${ }^{1}$ University of Kragujevac, Serbia, Faculty of Medical Sciences, Department of Hygiene and ecology ${ }^{2}$ University of Kragujevac, Serbia, Faculty of Hotel Management and Tourism, Vrnjacka Banja ${ }^{3}$ Institute of Public Health, Kragujevac, Serbia

\author{
PREVALENCA FAKTORA RIZIKA \\ KOD ŽENA SA OSTEOPOROZOM

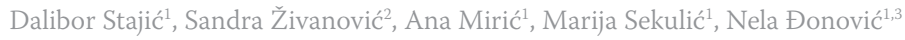 \\ ${ }^{1}$ Univerzitet u Kragujevcu, Srbija, Fakultet medicinskih nauka, Katedra za higijenu i ekologiju \\ ${ }^{2}$ Univerzitet u Kragujevcu, Srbija, Fakultet za hotelijerstvo i turizam, Vrnjačka Banja \\ ${ }^{3}$ Institut za javno zdravlje, Kragujevac, Srbija
}

\begin{abstract}
Osteoporosis is a progressive bone disorder that can be influenced by many different factors. A cross-sectional study has been conducted with the aim to assess the prevalence of risk factors as well as to identify the possible causes of improvement of the disease. The study population consisted of 97 women older than 35 who had previously been diagnosed with osteoporosis. Dualenergy X-ray Absorptiometry (DXA) scan was used to determine bone mineral density (BMD) in order to assess the current state of the disease. The participants were asked to complete a standardized IOF (International Osteoporosis Foundation) questionnaire. According to BMD measurements, $24.7 \%$ of women had normal bone density while $18.6 \%$ had T-score lower than -2.5 . There was a statistically significant correlation between T-score and the history of previous bone fractures. Besides, a relatively high prevalence of certain risk factors (such as underweight, early menopause, oophorectomy, thyroid and parathyroid disorders etc.) was observed in woman with osteoporosis.
\end{abstract}

Keywords: osteoporosis; osteopenia; bone mineral density; T-score; risk factors

\section{SAŽETAK}

Osteoporoza predstavlja progresivni poremećaj kostiju koji nastaje pod uticajem velikog broja faktora.Studija preseka je sprovedena sa ciljem da se proceni prevalenca faktora rizika, kao i da se identifikuju eventualni uzroci poboljšanja bolesti. Studija je obuhvatila 97 žena, starijih od 35 godina, sa prethodno dijagnostikovanom osteoporozom. Metod dvostruke apsorpciometrije X-zraka (DXA) je upotrebljen $z a$ odredivanje mineralne gustine kostiju (BMD) $i$ procenu trenutnog stanja bolesti. Učesnice su popunjavale standardizovani IOF upitnik. Na osnovu merenja BMD, 24.7\% žena je imalo normalnu gustinu kostiju, dok je kod 18,6\% određen T-skor niži od -2,5. Dobijena je statistički značajna povezanost T-skora sa istorijom preloma. Osim toga, dobijena je relativno visoka prevalenca određenih faktora rizika (kao što su pothranjenost, rana menopauza, ooforektomija, poremećaji tiroidne i paratiroidne žlezde itd) kod žena sa osteoporozom.

Ključne reči: osteoporoza; osteopenija; mineralna gustina kostiju; T-skor; faktori rizika

\section{ABBREVIATIONS}

BMD - bone mineral density

BMI - body mass index

\section{INTRODUCTION}

Osteoporosis is a progressive skeletal disorder characterized by low bone mass, compromised bone structure and increased risk of fractures (1). It affects more than 75 million people in Europe, Japan and the USA (2), and therefore it represents a serious public health problem. Every year it causes about 9 million of fractures worldwide (3). According to statistics, 1 in 3 women as well as 1 in 5 men aged over 50 experience osteoporotic fractures. Based on bone mineral density (BMD), the following categories have been established (4):

- Normal bone structure - BMD is less than 1 standard deviation (SD) below the young adult mean value ( $\mathrm{T}$ score $\geq-1)$;

- Osteopenia - BMD is between 1 and 2.5 SD below the young adult mean value $(-2.5<\mathrm{T}$-score $<-1)$;

- Osteoporosis - BMD is more than 2.5 SD below the young adult mean value ( $\mathrm{T}$-score $\leq-2.5$ );

- Severe osteoporosis - BMD is 2.5 SD or more below the young adult reference mean in the presence of fragility fractures. 
Several unchangeable predictors of osteoporosis have been identified, such as genetics, age, gender, some chronic diseases etc. On the other hand, there are some factors that can be controlled in order to prevent the disease and decrease the occurrence of fractures. These are dietary patterns, nutritional status, cigarette smoking, physical activity, alcohol use etc. The aim of this study was to investigate the current state of the disease as well as the prevalence and the role of certain risk factors among patients who had previously been diagnosed with osteoporosis.

\section{MATHERIAL AND METHODS}

A cross-sectional study has been carried out using a simple random sampling method. The study population consisted of 97 female patients older than 35, who had previously been diagnosed with osteoporosis. The size of the sample was determined using G-power 3.0.10 (with an assumed power of 0.80 and significance level $\alpha=0.05$ ). The study was conducted during the year 2014-2015, in the Health Centre Kragujevac, Serbia.

All participants were subjected to Dual-energy X-ray Absorptiometry (DXA) scan in order to determine BMD, T-score (deviation of patient's BMD from the reference BMD of a healthy 30-year old adult) and Z-score (deviation of BMD from age-matched reference value). In addition, the participants were also asked to fill out a standardized IOF (International Osteoporosis Foundation) questionnaire (5). It included questions regarding family anamnesis, lifestyles, history of fractures, diseases and medications. Anthropometric measurements were performed in order to calculate body mass index (BMI) of all respondents.

Statistical analyzes were done using SPSS 20.0 computer software. Data were tested for normality using Kolmogorov-Smirnov test. Spearman bivariate correlation analyzes were applied in order to investigate the correlations between quantitative variables, while chi-square $\left(x^{2}\right)$ test was used for analyzing categorical data. Differences were considered statistically significant at $\mathrm{p} \leq 0.05$.

\section{RESULTS}

Table 1 presents descriptive statistics of quantitative variables investigated in the study. The age of the participants ranged from 38 to 83 , with a mean of $62.5 \pm 8.7$. $\mathrm{T}$-score and Z-score were determined based on measured

Table 1. Descriptive statistics of quantitative variables

\begin{tabular}{ccccc}
\hline & Minimum & Maximum & Average & $\begin{array}{c}\text { Standard } \\
\text { deviation }\end{array}$ \\
\hline Age & 38 & 83 & 62.5 & 8.7 \\
Menopause & 20 & 58 & 42.8 & 14.1 \\
BMD & 0.19 & 0.85 & 0.41 & 0.13 \\
T-score & -3.60 & 0.50 & -1.68 & 0.94 \\
Z-score & -3.20 & 1.20 & -0.86 & 0.92 \\
\hline
\end{tabular}

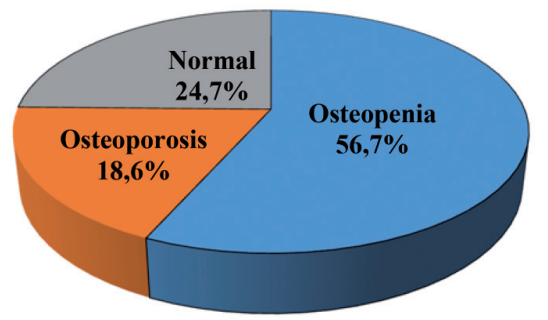

Figure 1. Classification of the participants according to the measured T-score value

BMD. According to current T-score, $24.7 \%$ of women had normal bone density, while $18.6 \%$ retained the diagnoses of osteoporosis (Figure 1). The rest of the participants were classified as osteopenic.

Table 2. Spearman correlation analyzes

\begin{tabular}{ccc} 
& Age & $\begin{array}{c}\text { Beginning of } \\
\text { menopause }\end{array}$ \\
\hline T-score & $-0,339$ & $-0,097$ \\
Z-score & 0,085 & 0,068 \\
\hline
\end{tabular}

The results of analyzing correlations between continuous variables are given in Table 2 . T-score was moderately negatively correlated with the age of the participants. There was a weak correlation of $\mathrm{T}$ - and Z-score with the age of beginning of menopause. Figure 2 presents T-score classification of the participants belonging to different age groups.

Table 3 presents the results of analyzing the data obtained using IOF questionnaire. Two categories $(\mathrm{df}=1)$ were considered while performing $\chi^{2}$ test: women with normal BMD (T-score > -1) and women with osteopenia or osteoporosis ( T-score $<-1$ ). As expected, a significantly higher percentage of women with $\mathrm{T}$-score $<-1$ experienced bone fractures after a minor fall. No other statistically significant difference was found between these two categories.

\section{DISCUSSION}

According to BMD measurements, a significant improvement of the disease was observed in $24.7 \%$ of patients who had previously been diagnosed with osteoporosis. In addition, $56.7 \%$ of women were classified as osteopenic. This amelioration could be the result of combined effects of many different factors that can influence the development of the disease. As expected, the ratio of normal to osteoporotic cases decreased with increasing age of the participants (Figure 2).

Previous studies have indicated that bone mineral density is highly (60-80\%) dependent on genetic factors $(6,7)$. About $24 \%$ of all respondents participating in our study have reported having one or both parents with the diag- 


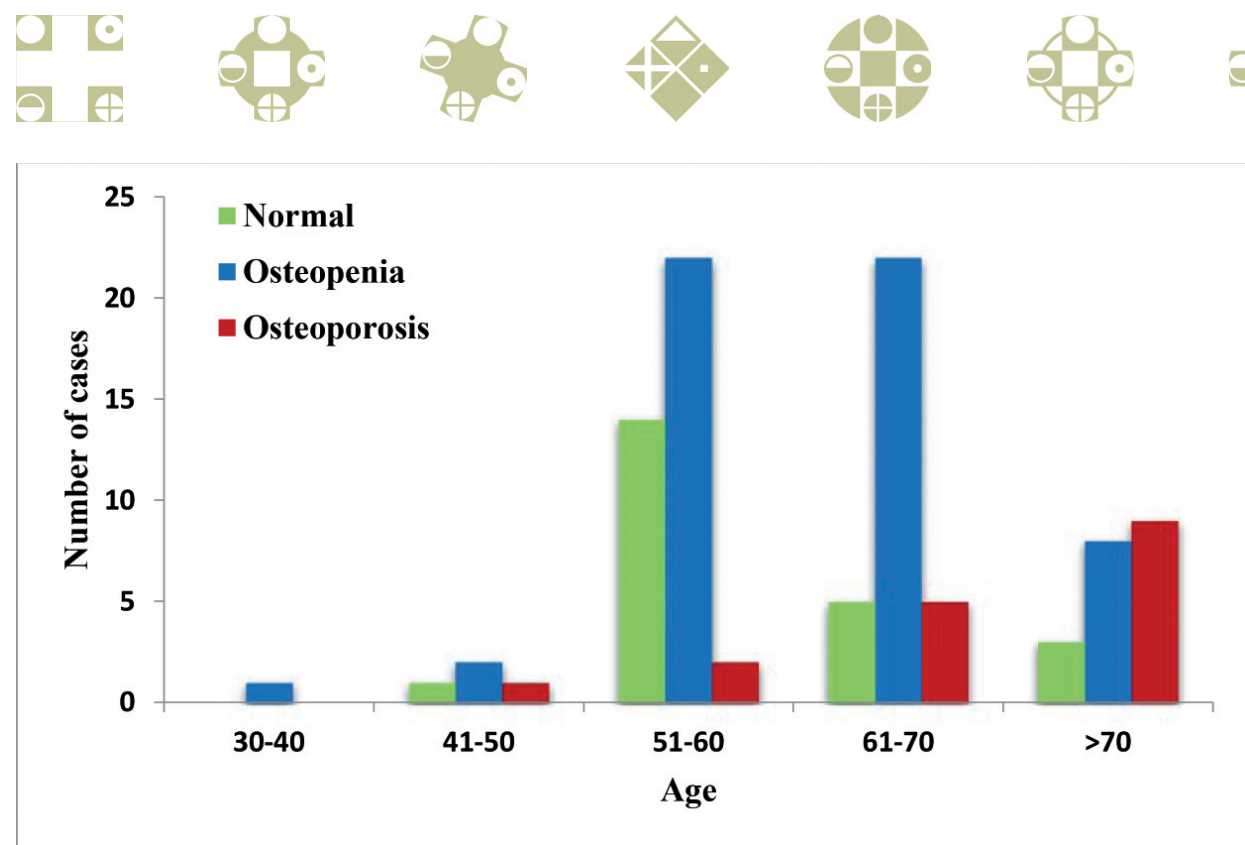

Figure 2. Number of participants with normal BMD, osteopenia and osteoporosis in different age intervals

nosis of osteoporosis. The prevalence of such cases was higher among the women with T-score $<-1$. Besides, more women with osteopenia or osteoporosis had bone fractures in the past (in comparison to those with normal BMD).
This difference was statistically significant $(\mathrm{p}=0.028)$ and it was in agreement with some previous studies that also found a strong correlation of BMD with the history of falls and fractures [8].

Table 3. The analyzes of categorical data obtained from IOF One-Minute Test

\begin{tabular}{|c|c|c|c|c|c|c|c|c|}
\hline \multirow{2}{*}{ IOF One-Minute Test } & \multicolumn{2}{|c|}{$\begin{array}{c}\text { Normal } \\
{[\%]}\end{array}$} & \multicolumn{2}{|c|}{$\begin{array}{c}\text { Osteopenia } \\
{[\%]}\end{array}$} & \multicolumn{2}{|c|}{$\begin{array}{c}\text { Osteoporosis } \\
{[\%]}\end{array}$} & \multirow[t]{2}{*}{$x^{2}$} & \multirow[t]{2}{*}{$\mathbf{p}$} \\
\hline & YES & NO & YES & NO & YES & NO & & \\
\hline $\begin{array}{l}\text { 1. Have either of your parents been diagnosed with osteoporosis or } \\
\text { broken a bone after a minor fall? }\end{array}$ & 17.4 & 82.6 & 24.5 & 75.5 & 25.0 & 75.0 & 0.112 & 0.737 \\
\hline 2. Did either of your parents have a stooped back (dowager's hump)? & 8.7 & 91.3 & 7.4 & 92.6 & 23.5 & 76.5 & 0.000 & 1.000 \\
\hline 3. Are you 40 years old or older? & 100.0 & 0.0 & 98.2 & 1.8 & 100.0 & 0.0 & 0.000 & 1.000 \\
\hline 4. Have you ever broken a bone after a minor fall, as an adult? & 20.8 & 79.2 & 50.0 & 50.0 & 52.9 & 47.1 & 4.807 & 0.028 \\
\hline $\begin{array}{l}\text { 5. Do you fall frequently (more than once in the last year) or do you have } \\
\text { a fear of falling? }\end{array}$ & 33.3 & 66.7 & 25.9 & 74.1 & 41.2 & 58.8 & 0.044 & 0.834 \\
\hline $\begin{array}{l}\text { 6. After the age of } 40 \text {, have you lost more than } 3 \mathrm{~cm} \text { in height (just over } 1 \\
\text { inch)? }\end{array}$ & 39.1 & 60.9 & 51.0 & 49.0 & 76.5 & 23.5 & 1.233 & 0.267 \\
\hline 7. Are you underweight $\left(\mathrm{BMI}<19 \mathrm{~kg} / \mathrm{m}^{2}\right)$ ? & 22.7 & 77.3 & 17.6 & 82.4 & 41.2 & 58.8 & 0.017 & 0.772 \\
\hline $\begin{array}{l}\text { 8. Have you ever taken corticosteroid tablets for more than } 3 \text { consecutive } \\
\text { months? }\end{array}$ & 8.3 & 91.7 & 17.3 & 82.7 & 18.8 & 81.3 & 0.482 & 0.505 \\
\hline 9. Have you ever been diagnosed with rheumatoid arthritis? & 13.6 & 86.4 & 13.2 & 86.8 & 11.8 & 88.2 & 0.000 & 1.000 \\
\hline $\begin{array}{l}\text { 10. Have you been diagnosed with an overactive thyroid or overactive } \\
\text { parathyroid glands? }\end{array}$ & 18.2 & 81.8 & 27.3 & 72.7 & 23.5 & 76.5 & 0.159 & 0.690 \\
\hline 11. Did your menopause occur before the age of 45 ? & 41.7 & 58.3 & 42.6 & 57.4 & 40.0 & 60.0 & 0.000 & 1.000 \\
\hline 12. Have your periods ever stopped for 12 consecutive months or more? & 0 & 100 & 9.1 & 90.9 & 0 & 100 & 0.546 & 0.335 \\
\hline $\begin{array}{l}\text { 13. Were your ovaries removed before age } 50 \text {, without you taking } \\
\text { Hormone Replacement Therapy? }\end{array}$ & 8.3 & 91.7 & 18.2 & 81.8 & 12.5 & 87.5 & 0.389 & 0.505 \\
\hline $\begin{array}{l}\text { 14. Do you regularly drink alcohol in excess of safe drinking limits (more } \\
\text { than } 2 \text { units a day)? }\end{array}$ & 0 & 100 & 0 & 100 & 0 & 100 & - & - \\
\hline 15. Do you currently, or have you ever, smoked cigarettes? & 30.0 & 70.0 & 41.2 & 58.8 & 35.7 & 64.3 & 0.157 & 0.692 \\
\hline 16. Is your daily level of physical activity less than 30 minutes per day? & 45.0 & 55.0 & 56.9 & 43.1 & 28.6 & 71.4 & 0.163 & 0.686 \\
\hline $\begin{array}{l}\text { 17. Do you avoid, or are you allergic to milk or dairy products, without } \\
\text { taking any calcium supplements? }\end{array}$ & 10.0 & 90.0 & 11.5 & 88.5 & 14.3 & 85.7 & 0.000 & 1.000 \\
\hline $\begin{array}{l}\text { 18. Do you spend less than } 10 \text { minutes per day outdoors, without taking } \\
\text { vitamin D supplements? }\end{array}$ & 26.3 & 73.7 & 19.2 & 80.8 & 23.1 & 76.9 & 0.000 & 1.000 \\
\hline
\end{tabular}


Low body mass index (BMI) has been identified as an important risk factor for development of osteoporosis due to low intake of energy and micronutrients $(9,10)$. Besides, estrogens have positive effects on preserving bone mass by affecting the metabolism of $\mathrm{Ca}, \mathrm{P}$ and vitamin D [11]. Aromatase (an enzyme expressed in gonads and fat tissue) synthesizes estrogens from androgen precursors. Synthesis in adipose tissue is the dominant source of estrogens in postmenopausal women therefore a high body mass index was assumed to have protective effect on bone degradation [12,13]. In this study, $41.2 \%$ of women with T-score $<-2.5$ had BMI lower than $19 \mathrm{~kg} / \mathrm{m}^{2}$. Totally $24.2 \%$ of all participants were underweight, which is rather high in comparison to the prevalence of underweight reported by Grujic et al. for healthy adult females in Serbia (14). This confirms the fact that individuals with low BMI have higher susceptibility to osteoporotic disorders. Besides, $76.5 \%$ of women with T-score $<-2.5$ had lost more than $3 \mathrm{~cm}$ in height after the age of 40 , which is almost double the percentage obtained for the women with normal BMD (39.1\%).

Furthermore, many studies have suggested that different lifestyles can affect bone mineral density. Smoking and alcohol consumption are usually considered to promote development of the disease $(8,15)$. The results of our study could not confirm this assumption since all the participants denied consumption of alcoholic drinks. Besides, the percentage of smokers was almost equal in all $\mathrm{T}$-score categories and it was comparable to the data obtained in healthy population (16). Moreover, extensive studies have supported positive effects of physical activity on bone formation, reduction of bone loss and prevention of fractures $(17,18)$. Totally, $48.8 \%$ of women in this study reported having less than 30 minutes of physical activities per day (including housework, gardening, walking, running etc.). Unexpectedly, women with T-score $<-2.5$ appeared to be more physically active than others. However, a statistically significant correlation between physical activity and T-score was not found.

Hormonal changes occurring in menopause increase the rate of bone degradation. The decrease in estrogen levels leads to enhanced risk of osteoporosis (19). Reduced production of hormones is also responsible for increased susceptibility to osteoporotic disorders in women with removed ovaries. Totally $41.5 \%$ of women participating in our study had entered menopause before the age of 45 . Besides, $14.6 \%$ of women reported having had oophorectomy before the age of 50 without using hormonal substitution. The prevalence of oophorectomy was slightly higher among women with T-score $<-1$ although this difference was not statistically significant.

Long-term corticosteroid therapy induces bone loss by causing osteoblastic suppression and increased bone resorption (20). The percentage of woman who had taken corticosteroid tablets for more than 3 consecutive months was more than two times higher in the group with T-score $<-2.5(18.8 \%)$ compared to the group with normal BMD (8.3\%).

Thyroid and parathyroid hormones have direct catabolic effect on bone mineral homeostasis; they stimulate bone mineral resorption and calcium loss (21). In our study, $24.2 \%$ of all participants reported having overactive thyroid or parathyroid glands. There was no strong correlation between T-score and the incidence of these disorders. However, the prevalence of hyperthyroidism and hyperparathyroidism was rather high in comparison to the prevalence of $0.5-2 \%$ obtained for general female population $(22,23)$.

Calcium and vitamin D have been identified as the most important micronutrients that enable achieving peak bone mass in youth and prevention of bone loss with aging. Dairy products are the main sources of calcium due to the high content and high absorption rate (24). Besides, calcium and vitamin D supplementation are extensively used in treatment of osteoporosis. $12.6 \%$ of the respondents in this study reported avoiding milk and milk products as well as calcium supplements. In addition, $21.2 \%$ of women spent less than 10 minutes per day outdoors, without using vitamin D supplementation.

\section{CONCLUSION}

Comparing to general population data, a high prevalence of some risk factors was obtained in a group of women diagnosed with osteoporosis. There is a significant correlation between T-score and the history of bone fractures. The improvement of the disease is probably the result of many different factors, including lifestyles and habits, history of diseases and medications, as well as therapy adherence and persistence. Therefore, a special care should be devoted to informing women with osteopenia and osteoporosis about all possible factors that might affect the course of the disease and improve the quality of life.

\section{ACKNOWLEDGMENTS}

We thank to the Health Centre Kragujevac for the collaboration in data collection.

\section{REFERENCES}

1. Osteoporosis Prevention, Diagnosis, and Therapy. NIH Consens Statement 2000, 27-29; 17(1): 1-36.

2. WHO (2003). Prevention and Management of Osteoporosis. WHO Technical Report Series 919. Geneva:World Health Organization

3. Johnell O, Kanis JA. (2006). An estimate of the worldwide prevalence and disability associated with osteoporotic fractures. Osteoporosis Int. 17(12), 1726-33. DOI: 10.1007/s00198-006-0172-4. 
4. Kanis JA, Melton LJ 3rd, Christiansen C, Johnston CC, Khaltaev N. (1994). The diagnosis of osteoporosis. J Bone Miner Res. 9(8), 1137-41. DOI: 10.1002/ jbmr.5650090802.

5. IOF One-Minute Osteoporosis Risk Test. Aveliable at: https://www.iofbonehealth.org/sites/default/files/ PDFs/2012-IOF_risk_test-english\%5BWEB\%5D_0.pdf

6. Krall EA, Dawson-Hughes B. (1993). Heritable and life-style determinants of bone mineral density. J Bone and Mineral Research. 8 (1), 1-9. DOI: 10.1002/ jbmr.5650080102.

7. Gueguen R, Jouanny P, Guillemin F, Kuntz C, Pourel J, Siest G. (1995). Segregation analysis and variance components analysis of bone mineral density in healthy families. J Bone Miner Res. 10, 2017-2022. DOI: 10.1002/jbmr.5650101223.321

8. Hans D, Durosier C, Kanis JA, Johansson H, SchottPethelaz AM, Krieg MA. (2008). Assessment of the 10 -year probability of osteoporotic hip fracture combining clinical risk factors and heel bone ultrasound: the EPISEM prospective cohort of 12,958 elderly women. J Bone Miner Res. 23(7), 1045-51. DOI: 10.1359/ jbmr.080229.

9. Asomaning K, Bertone-Johnson ER, Nasca PC, Hooven F, Pekow PS. (2006). The association between body mass index and osteoporosis in patients referred for a bone mineral density examination. J Womens Health (Larchmt). 15(9), 1028-34. DOI: 10.1089/jwh.2006.15.1028.

10. Fawzy T, Muttappallymyalil J, Sreedharan J, Ahmed A, Alshamsi SO, Al Ali MS, Al Balsooshi KA. (2011). Association between Body Mass Index and Bone Mineral Density in Patients Referred for Dual-Energy X-Ray Absorptiometry Scan in Ajman, UAE. J Osteoporos. 2011,876309. DOI: 10.4061/2011/876309.

11. Gallagher JC, Riggs BL, DeLuca HF. (1980). Effect of estrogen on calcium absorption and serum vitamin D metabolites in postmenopausal osteoporosis. J Clin Endocrinol Metab. 51(6),1359-1364.

12. Siiteri PK. (1987). Adipose tissue as a source of hormones. Am J Clin Nutr. 45(1 Suppl), 277-282.
13. Migliaccio S, Greco EA, Fornari R, Donini LM, Lenzi A. (2011). Is obesity in women protective against osteoporosis? Diabetes Metab Syndr Obes. 4, 273-282.

14. Grujić V, Dragnić N, Radić I, Harhaji S, Susnjević S. (2010). Overweight and obesity among adults in Serbia: results from the National Health Survey. Eat Weight Disord. 15(1-2), 34-42.

15. Hauser B, Riches PL, Wilson JF, Horne AE, Ralston SH. (2014). Prevalence and clinical prediction of osteoporosis in a contemporary cohort of patients with rheumatoid arthritis. Rheumatology (Oxford). 53(10), 175966. DOI: 10.1093/rheumatology/keu162.

16. WHO Report on the Global Tobacco Epidemic, 2015. Available at: http://www.who.int/tobacco/surveillance/ policy/country_profile/srb.pdf.

17. Schmitt NM, Schmitt J, Dören M. (2009). The role of physical activity in the prevention of osteoporosis in postmenopausal women-An update. Maturitas. 20;63(1), 34-38. DOI: 10.1016/j.maturitas.2009.03.002.

18. Borer KT. (2005). Physical activity in the prevention and amelioration of osteoporosis in women : interaction of mechanical, hormonal and dietary factors. Sports Med. 35(9), 779-830.

19. WHO Scientific Group on the Prevention and Management of Osteoporosis (2000 : Geneva, Switzerland) (2003).

20. Picado C, Luengo M. (1996). Corticosteroid-induced bone loss. Prevention and management. Drug Saf. 15(5), 347-59.

21. Dhanwal DK. (2011). Thyroid disorders and bone mineral metabolism. Indian J Endocrinol Metab. 15(2), 107-12. DOI: $10.4103 / 2230-8210.83339$

22. Vanderpump MP. (2011). The epidemiology of thyroid disease. Br Med Bull. 99, 39-51. DOI: 10.1093/bmb/ ldr030

23. Adami S, Marcocci C, Gatti D. (2002). Epidemiology of primary hyperparathyroidism in Europe. J Bone Miner Res. 17(2), 18-23.

24. Sunyecz JA. (2008). The use of calcium and vitamin $\mathrm{D}$ in the management of osteoporosis. Ther Clin Risk Manag. 4(4), 827-36. 